\title{
Postpartum reproductive tract score in beef cows - a proposed method
}

\author{
L.M.J. Schwalbach ${ }^{\#}$, J.P.C. Greyling and G.J. Taylor \\ Dept. of Animal Science, UOFS, POBox 339, Bloemfontein, 9300, South Africa \\ \#Email: Sch@landbou.uovs.ac.za
}

\section{Introduction}

The assessment of the reproductive potential of postpartum cows is usually indirectly done by assessing nutritional status using body weight (BW) and body condition score (BCS). Direct assessment methods include uterine involution and/or resumption of the ovarian activity. These criteria are qualitative and there is no direct established relationship between these two criteria and reproductive performance. Recently a method was developed to directly access the heifer's reproductive potential, namely reproductive tract score (RTS). This technique comprises a physical examination of the reproductive tract (Anderson et al., 1991). This study was aimed at evaluating a proposed RTS method for postpartum beef cows as a predictor of subsequent reproductive performance.

\section{Materials and Methods}

The reproductive tracts of 117 postpartum mature Bonsmara cows with a BCS varying between 2.5 and 4 , nursing 1 to 3 month old calves was examined 30 days before and at the onset of a 63 day summer mating period. The status of uterine involution and the resumption of the ovarian activity were assessed using the methods described by Wiltbank et al. (1962) and Rutter \& Randel (1984). The RTS was also evaluated in each cow based on criteria adapted from the method of Anderson et al. (1991) for beef heifers. These criteria also take into consideration the most common abnormalities detected during the gynaecological examination of postpartum cows (Table 1). These findings were related to the conception rates established at pregnancy diagnosis by rectal palpation 60 days after the breeding season, and later reconfirmed at calving. Data was analysed using procedures of SAS (1991).

Table 1 Criteria used for determining reproductive tract score (RTS) in postpartum cows

\begin{tabular}{|c|c|c|c|c|}
\hline RTS & Vulva \& Vagina & Cervix & Uterus & Ovaries \\
\hline 1 & $\begin{array}{l}\text { Purulent discharge, } \\
\text { Recto-vaginal } \\
\text { fistulae. } \\
\text { Pale mucosae. }\end{array}$ & $\begin{array}{l}\text { On the pelvic brim. } \\
\text { Not involuted. } \\
\text { Cervicitis. } \\
\text { Severe fibrosis. }\end{array}$ & $\begin{array}{l}\text { Not involuted, asymmetric. } \\
\text { Over the pelvic brim. } \\
\text { Irregular surface, with } \\
\text { content. }\end{array}$ & $\begin{array}{l}\text { Not active. } \\
\text { No palpable } \\
\text { structures. } \\
\text { Flat and small }\end{array}$ \\
\hline 2 & $\begin{array}{l}\text { Vaginitis or severe } \\
\text { vulvae lesions with } \\
\text { consequences to the } \\
\text { shape and closure }\end{array}$ & $\begin{array}{l}\text { Intrapelvic. } \\
\text { Not completely } \\
\text { involuted. } \\
\text { Mild cervicitis. } \\
\text { Mild fibrosis. }\end{array}$ & $\begin{array}{l}\text { Not completely involuted. } \\
\text { At the brim. Distinct } \\
\text { asymmetry }(1: 1.5) \text {. } \\
\text { Thick wall with content. } \\
\text { No tone }\end{array}$ & $\begin{array}{l}\text { Not active. } \\
\text { No palpable } \\
\text { structures, but not } \\
\text { flat. }\end{array}$ \\
\hline 3 & $\begin{array}{l}\text { Vulvae lesions with } \\
\text { consequences to the } \\
\text { shape, but normal } \\
\text { closure. } \\
\text { Dry pale/pink } \\
\text { mucosae }\end{array}$ & $\begin{array}{l}\text { Intrapelvic. } \\
\text { Involuted, but with a } \\
\text { small area of } \\
\text { fibrosis (scar tissue) }\end{array}$ & $\begin{array}{l}\text { Not completely involuted. } \\
\text { Uterus intra-pelvic, nearly } \\
\text { symmetrical }(1: 1.2) \text {. } \\
\text { Thin wall, with no content. } \\
\text { No tone. }\end{array}$ & $\begin{array}{l}\text { Small developing } \\
\text { follicles } \\
(<5 \mathrm{~mm}) . \\
\text { Rounded ovaries }\end{array}$ \\
\hline 4 & $\begin{array}{l}\text { Normal. } \\
\text { Moist pink mucosae }\end{array}$ & $\begin{array}{l}\text { Intrapelvic. } \\
\text { Normal. }\end{array}$ & $\begin{array}{l}\text { Involuted. Intrapelvic. } \\
\text { Symmetrical (1: } 1.1) \text {. Thin } \\
\text { wall, with no content. } \\
\text { Good tone }\end{array}$ & $\begin{array}{l}\text { One ovary active, } \\
\text { with follicles } \\
\text { (>10mm) } \\
\text { CL possible }\end{array}$ \\
\hline 5 & $\begin{array}{l}\text { Normal. } \\
\text { Moist pink mucosae }\end{array}$ & $\begin{array}{l}\text { Intrapelvic. } \\
\text { Normal. }\end{array}$ & $\begin{array}{l}\text { Involuted.Intrapelvic. } \\
\text { Symmetrical }(1: 1.1) \text {. } \\
\text { Thin wall, with no content. } \\
\text { Excellent tone }\end{array}$ & $\begin{array}{l}\text { Both ovaries active, } \\
\text { with follicles } \\
\text { (>10mm). } \\
\text { CL present }\end{array}$ \\
\hline
\end{tabular}

\section{Results and Discussion}

The results obtained by rectal examination of the postpartum cows 30 days postpartum and at the onset of the breeding period are presented in Table 2. 
Short paper and poster abstracts: $38^{\text {th }}$ Congress of the South African Society of Animal Science

Table 2 Uterine involution and resumption of ovarian activity during the postpartum period

\begin{tabular}{cccccc}
\hline Time & No of cows & \multicolumn{2}{c}{ Uterine involution } & \multicolumn{2}{c}{ Ovarian activity } \\
\hline Postpartum & $(\mathrm{n})$ & Complete & Not complete & Resumed & Not-resumed \\
30 days & 108 & $82(76 \%)$ & $26(24 \%)$ & $41(38 \%)$ & $67(62 \%)$ \\
At mating & 117 & $95(82 \%)$ & $22(18 \%)$ & $84(72 \%)$ & $33(28 \%)$ \\
\hline
\end{tabular}

There was no difference in the uterine involution status of the cows between 30 days postpartum and at beginning of the breeding period. The majority of the cows (76\%) had clinically completed uterine involution by 30 days postpartum. Contrary to this, ovarian activity was low at 30 days postpartum (38\%), but improved to $72 \%$ at the onset of the breeding period. No significant relationship was established between the uterine involution, the resumption of ovarian activity at 30 days postpartum or at the onset of breeding and subsequent conception rates. This was because some of the cows that have completed uterine involution had not resumed ovarian activity and some cows with active ovaries had not completed uterine involution, due to a late calving date in the season and/or uterine infection (pyometra). The frequency distribution of the RTS at 30 days postpartum and at the onset of a 63 days summer breeding period and its relationships to conception rates is set out in Table 3.

Table 3 Relationship between postpartum reproductive tract score and conception rate

\begin{tabular}{ccccccc}
\hline RTS & \multicolumn{3}{c}{ At 30 days postpartum $(\mathrm{n}=103)$} & \multicolumn{3}{c}{ At onset of breeding $(\mathrm{n}=117)$} \\
Score & Total & Pregnant & $\%$ & Total & Pregnant & $\%$ \\
\hline 1 & - & - & & 4 & 0 & $0^{\mathrm{a}}$ \\
2 & 14 & 5 & $36 \%^{\mathrm{a}}$ & 14 & 3 & $21^{\mathrm{a}}$ \\
3 & 62 & 47 & $76 \%^{\mathrm{b}}$ & 38 & 23 & $61^{\mathrm{b}}$ \\
4 & 27 & 25 & $93 \%^{\mathrm{c}}$ & 46 & 42 & $91^{\mathrm{c}}$ \\
5 & - & - & - & 15 & 15 & $100^{\mathrm{c}}$ \\
\hline
\end{tabular}

The frequency distribution of the RTS at 30 days postpartum and at the onset of a 63 days summer breeding period and its relationship to conception rates is set out in Table 3. At 30 days postpartum, the RTS ranged between 2 and 4, with no animals in the 1 and 5 category. At breeding, there were cows in all 5 RTS groups. In both cases, the majority of cows were in the 3 and 4 RTS categories, indicating complete uterine involution and detectable ovarian activity. RTS at these two phases of the postpartum period significantly $(\mathrm{P}<0.05)$ affected the subsequent conception rates. In general, a higher RTS corresponded to higher conception rates. Statistical differences between RTS 1 and 2 as well as between RTS 4 and 5 could not be established. No cow with a RTS of 1 and very few with a score of 2 conceived throughout the breeding period. Results further show conception to occur earlier in cows with higher scores (4 and 5) at the onset of the mating period. Most cows with a score of 3 showed sub-optimal conception rates and conceived only in the last third of the breeding period.

\section{Conclusion}

The proposed RTS method for postpartum cows seems to be a good predictor of subsequent reproductive performance in beef cows.

\section{References}

Anderson, K.J., LeFever, D.G., Brinks, J.S. \& Adde, K.G., 1991. The use of reproductive tract score in beef heifers. Agri-practice, 12 (4), 19-26

Rutter L.M. \& Randel,R.D., 1984. Luteal competency during the resumption of ovarian cyclicity in postpartum Brahman cows. Theriogenology, 21, 713-725

Wiltbank, J.N.,Rowden, E.J., Ingalls, J.E., Gregory, K.E. \& Koch, R.M., 1962. Effect of energy level on the reproductive phenomena of mature Hereford cows.J. Anim. Sci., 21, 219-225.

SAS, 1991. SAS/STAAT for P.C.- User's guide. Release 6.0 Edition.SAS®, Inc.Cary, North Carolina, USA. 